\title{
A Comparative Investigation of Groundwater Contamination in Typical Dumpsites and Cemetery Using Ert and Physicochemical Analysis of Water in Benin Metropolis, Nigeria
}

\author{
Osabuohien Idehen \\ Department of Physics, Faculty of Sciences, Tayo Akpata University of Education, (Formally College of Education), \\ Ekiadolor, Benin \\ Email: idehenosabuohien@gmail.com
}

How to cite this paper: Idehen, O. (2020). A Comparative Investigation of Groundwater Contamination in Typical Dumpsites and Cemetery Using Ert and Physicochemical Analysis of Water in Benin Metropolis, Nigeria. Journal of Geoscience and Environment Protection, 8, 72-85.

https://doi.org/10.4236/gep.2020.81005

Received: June 29, 2019

Accepted: January 13, 2020

Published: January 16, 2020

Copyright $\odot 2020$ by author(s) and Scientific Research Publishing Inc. This work is licensed under the Creative Commons Attribution International License (CC BY 4.0).

http://creativecommons.org/licenses/by/4.0/

\begin{abstract}
This paper investigated the comparative analysis of groundwater contamination in Third Cemetery and Costain Dumpsite in Benin Metropolis, South South of Nigeria, using Electrical Resistivity Tomography (ERT) and Physicochemical analysis of water. The implications of land utilization for burial of dead human bodies in the form of cemeteries, many cases associated with coffin and caskets used for interment of remains and the location of refuse dump have received no consideration in Nigeria. Interment of bodies in cemeteries and dumping of refuse in dumpsites remain widespread practice and the only alternative endpoint to dead bodies and disposal of wastes in Nigeria. In Nigeria, this practice had not been perceived as having a significant potential contaminant effect in the environment and especially the groundwater component as search of literature attracted no such study to the country. In Benin City and Nigeria in general, the major cemeteries and dumpsites are located close to human residential areas and virtually all the populace within this locality depends on groundwater as the primary water source for various domestic purposes. Res2Dinv was employed in both sites as the geophysical method. The investigation of cemeteries is always difficult and challenging task in geoforensic prospective. Most researchers assess the impact of interment on the environment by comparing study results from cemeteries with data from reference sites. This study is based on this premise. The 2-D Geological Models showed that both Third Cemetery and Costain Dumpsite contained leachate plumes of various degrees as indicated by the low resistivity values, which infiltrated into the groundwater. The values of Water Quality Index (WQI) of groundwater samples in Third Cemetery and Costain
\end{abstract}


Dumpsite were found to be 13.40 and 21.58 respectively which indicated that the quality of water at both Third Cemetery and Costain Dumpsite were good for drinking and other domestic purposes though with some degrees of contamination.

\section{Keywords}

Dumpsite, Cemetery, Contamination, 2-D Geoelectric Model, Physicochemical Groundwater

\section{Introduction}

Groundwater is an important freshwater resource in both the urban and rural areas of Nigeria (Adekunle et al., 2007). It is a valuable resource often considered for industry, commerce, agriculture, and domestic uses (most importantly for drinking). Various literatures have established a close relationship between land use and groundwater quality (Edet, 1993; Ikem et al., 2002; Majolagbe et al., 2011). Based on land use, sources of groundwater contamination include leachate from municipal refuse dumpsite, industrial discharge (liquid waste), domestic waste, salt water intrusion, application of agricultural chemicals, oil spillage and pipeline vandalisation and geological formations (Majolagbe et al., 2011). The issues of necroleachate represent a matter of concern because groundwater can be contaminated by such as they are laden with bacteria, viruses, nitrogen (N), phosphorus (P) (Neckel et al., 2016), and heavy metals and other toxic substances resulting from the decay of coffin material (Spongberg \& Becks, 2000; Jonker \& Olivier, 2012). These may be transported from the graves through seepage and percolate into surrounding soils and from there they may leach into groundwater and become a potential health risk to the residents depending on the contaminated water for various uses. The risk of contamination is influenced by soil nature and infiltration rate, types of burials, and the effect of rainfall on the groundwater level (Üçisik \& Rushbrook, 1998). Ucisik and Rushbrook (1998) also expressed that existing cemeteries in Benin City were sited without due consideration for the local environment and population dynamics. In some part of Benin City residential buildings exist as close as $5 \mathrm{~m}$ to the cemetery in some cases, and an example is the sitting of Third Cemetery at New Benin district.

The identification of individual graves through geophysical techniques is relatively problematic and thus in the prospection of cemeteries and graves, there are no rules or specific guidelines. The success of such a survey depends on the conservation of the graves, the various artifacts that may accompany a burial, the depth and dimensions of the burial, the environmental noise, the geology, etc. (Idehen, 2018). Studies on the impact of cemeteries and dumpsites on the quality of groundwater in unsaturated and saturated zones are usually conducted within or at some distance from the cemeteries and dumpsites (Schraps, 1972; Zy- 
chowski et al., 2000). Over $40 \%$ of cemeteries in South Africa contaminate water resources (Fisher \& Croukamp, 1993).

\section{Study Area (Third Cemetery and Costain Dumpsite)}

This study was conducted in Benin City located in South-South geopolitical zone of Nigeria. Benin City is the capital of Edo State, bounded by latitudes $06^{\circ} 06^{\prime} \mathrm{N}$, $06^{\circ} 30^{\prime} \mathrm{N}$ and longitudes $005^{\circ} 30^{\prime} \mathrm{E}, 005^{\circ} 45^{\prime} \mathrm{E}$ and an area of about 500 square kilometers (Idehen, 2019). The city is located within the rain forest ecological zone with annual mean temperature of $27.5^{\circ} \mathrm{C}$ (Ikhuoria, 1987) and an annual mean rain fall of about $2095 \mathrm{~mm}$ (Ikhile \& Olorode, 2011).

\subsection{Third Cemetery}

Three cemeteries namely First, Second and Third cemeteries are located within this city. The Third cemetery which has existed for over 50 years was considered for this study because of its proximity to human residents. The cemetery which is the biggest among the cemeteries in Benin City covers an area of about 5.167 ha (Ibhadode et al., 2017; Idehen, 2019). Water sample was collected in the periphery of the cemetery (Site 1) used for the physicochemical analysis of water.

Site, S1, from New Benin Police Station that was carved out of the cemetery

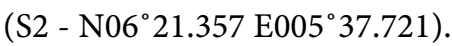

Geological siting of Benin City is underlain by sedimentary formation described by Short and Stauble (1967) (Figure 1).

\subsection{Costain Dumpsite}

This dumpsite was located at the end of Costain Road, Off Upper Mission Road, adjacent to New Benin Market about $2 \mathrm{~km}$ from Third Cemetery. It terminates at a valley that cuts across Ikpoba Slope. The GPS of this dumpsite gave the following: N 06 $20^{\prime} 56^{\prime \prime}$ South of Benin, E $005^{\circ} 38^{\prime} 15^{\prime \prime}+/-12 \mathrm{ft}$, Elevation $211 \mathrm{ft}$, Odometer $68.56 \mathrm{~m}$ (Idehen, 2018).

\section{Materials and Methods}

Electrical resistivity imaging data was acquired using Pasi Earth Resistivity Meter. The data coverage was made over an area defined by rectangular loop measuring $30 \mathrm{~m}$ by $200 \mathrm{~m}$. The electrical resistivity data was collected in seven equidistant lines as 2-D data set using Wenner-Schlumberger Array at $5 \mathrm{~m}$ interval in both periods. The first survey, the inter-electrode spacing in each line was $10 \mathrm{~m}$ while in the second survey was $5 \mathrm{~m}$. The resistance values read from the measuring instrument was then transformed to apparent resistivity using the geometrical factor each sequence of measurement. Wenner-Schlumberger spread was used.

\subsection{Field and Laboratory Analyses}

In order to characterize the physicochemical parameters of the water and further ascertain the suitability of these groundwater resources located near the 


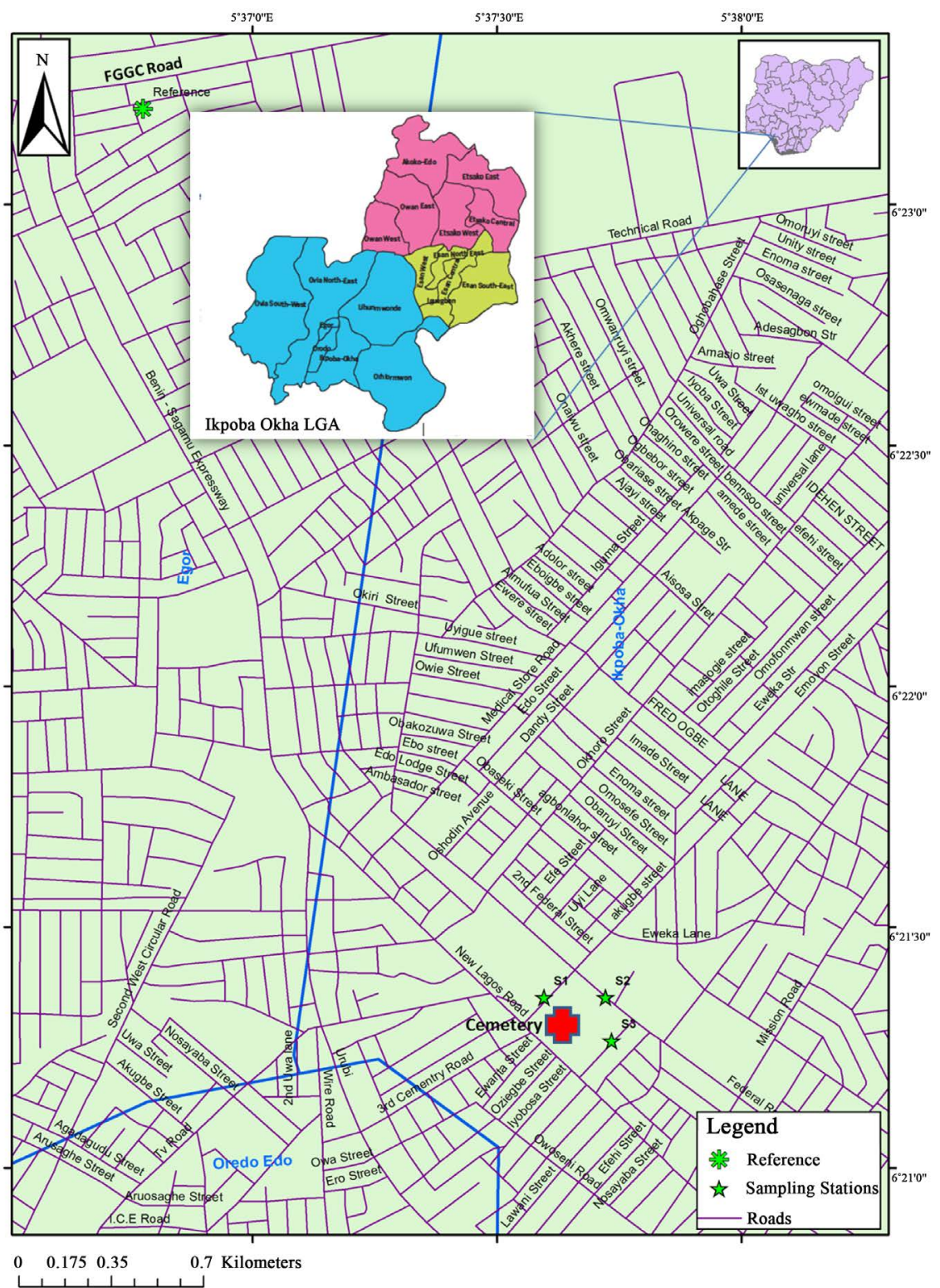

Figure 1. Map of study area (third cemetery and costain dumpsite).

cemetery and the dumpsite, equal replicate of water samples were collected from borehole located at the peripheral of the cemetery and dumpsite. At each of the boreholes, the discharge pipe of the boreholes was swabbed with cotton wool soaked in $70 \%$ ethanol and water samples were collected after flushing for 4 to 5 minutes. Sample for determination of other parameters other than in situ parameters, heavy metals component was collected with 1 litre plastic bottles. Sample for heavy metal determination was collected in acid washed polyethylene bottles. All samples collected were labeled properly and stored in iced coolers $\left(0^{\circ} \mathrm{C}-4^{\circ} \mathrm{C}\right)$. The samples were immediately taken to the laboratory and analyses were done within 24 hours of sample collection. In situ parameters including; electrical conductivity (EC), hydrogen ion concentration (pH) and total dissolved solids (TDS) were determined with the aid of Extech meter probes (Exstik II). In the laboratory, the 
analysis of other parameters including total suspended solids (TSS), calcium, magnesium, sulphate, nitrate, phosphate, chloride, calcium carbonate $\left(\mathrm{CaCO}_{3}\right)$, sodium, potassium, lead, copper, chromium, iron, zinc, manganese, cadmium, nickel, mercury, dissolved oxygen (DO), biochemical oxygen demand $\left(\mathrm{BOD}_{5}\right)$, chemical oxygen demand (COD) were done using standard methods adopted from APHA (1998); (Radojevic \&Bashkin, 1999, Idehen, \& Ezenwa, 2019).

\subsection{The Wenner-Schlumberger Array}

This array is the hybrid between the Wenner array and the Schlumberger array arising out of the recent work with electrical imaging surveys. This array is moderately sensitive to both horizontal structure and vertical structures (Loke, 2014) (Figure 2)

$$
\begin{gathered}
K=\operatorname{an} \pi(n+1) \\
\rho=K R
\end{gathered}
$$

That is apparent resistivity equals geometric factor times resistance.

$$
C_{1} \leftarrow n a \rightarrow P_{1} \leftarrow a \rightarrow P_{2} \leftarrow n a \rightarrow C_{2} \quad\{K=a n \pi(n+1)\}
$$

\subsection{Field Data Processing and Interpretation in Costain Dumpsite}

Res2Dinv software was used to process the data with Geoelectric images consisting of four graphs in each figure. The upper modeled (measured apparent resistivity pseudosection) with the raw apparent resistivity. The second graph represents model of the computer generated apparent resistivity data (calculated apparent resistivity pseudosection). These two graphs are termed pseudo section. The third graph (inverse model resistivity section) is produced with the inverted apparent resistivity data, which is the true subsurface resistivity. The third graph is what is used to deduce the geological make-up of the surveyed depth range. The model resistivity (true subsurface resistivity) data was exported to surfer window and then the resistivity pictures were transformed to geological ones. Sand image was used to show the background subsurface sediment imaged (the fourth graph-geology section), while red colour shade was used to define the area suspected to be contaminated by leachate plumes (less than $100 \mathrm{Ohm}-\mathrm{m}$ ), assuming clay is absent in the sediment, dominantly sand.

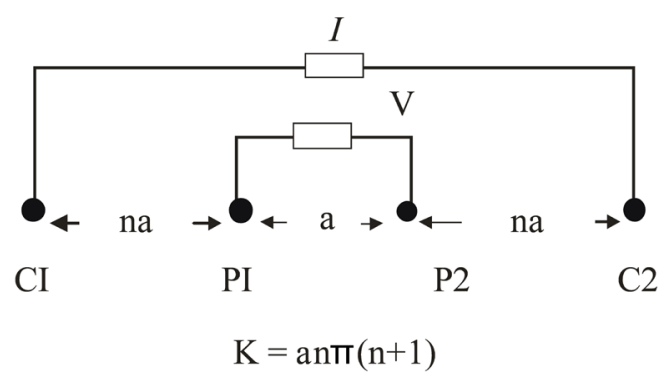

Figure 2. Wenner-Schlumberger Array (Anthony Ravindran \& Mohd. Abdul Kadar Prabhu, 2012). 


\section{Results (Table 1)}

\subsection{Physicochemical Analysis of Water in Costain Dumpsite}

The groundwater sample at Costain was slightly acidic and the $\mathrm{pH}$ was 6.200. According to Omoboriowo et al. (2012), acidity is probably caused by the presence of organic matter in the soils. Moreover, free $\mathrm{CO}_{2}$ from the atmosphere can also enter the groundwater system as rainwater percolates underground and reduce the $\mathrm{pH}$ of the water.

Conductivity is the ability to conduct electricity, heat or sound. Pure water is a bad conductor of electricity. Conductivity increases as the concentrations of ions in water sample increases. The conductivity value at Costain was $99.900 \mu \mathrm{S} / \mathrm{cm}$. This value was far below the stipulated value of $1000 \mu \mathrm{S} / \mathrm{cm}$ by NIS (2007). Conductivity also is a product of dissolved solids in water. The value of total dissolved solids at Costain was $53.000 \mathrm{mg} / \mathrm{l}$ compared with NIS (2007) stipulated value of $500 \mathrm{mg} / \mathrm{l}$.

Also the concentrations of calcium and magnesium did not differ significantly ( $p>0.05)$. The concentration of calcium was greater than that of magnesium. Similar trend was observed by Omofonmwan and Eseigbe (2009). The concentrations of magnesium did not compare favourably with the NIS (2007) stipulated value of $0.2 \mathrm{mg} / \mathrm{l}$; measure has to be adopted to reduce the concentration of magnesium in order to avoid the incidence of stomach irritation.

Table 1. Summary of selected physicochemical analysis of groundwater in a typical dumpsite and a typical cemetery.

\begin{tabular}{|c|c|c|c|c|}
\hline Parameters & $\begin{array}{c}\text { Costain } \\
\text { dumpsite }\end{array}$ & $\begin{array}{c}\text { Third } \\
\text { cemetery }\end{array}$ & $\begin{array}{c}\text { Reference } \\
\text { site }\end{array}$ & $\begin{array}{c}\text { Nis } \\
(2007)\end{array}$ \\
\hline $\mathrm{pH}$ & 6.200 & 4.960 & 6.800 & $6.50-8.50$ \\
\hline Conductivity (EC) & 99.900 & 118.000 & 12.000 & 1000.000 \\
\hline Total Dissolved Solid (TDS) & 53.000 & 59.000 & 6.300 & 500.000 \\
\hline Calcium & 2.400 & 3.840 & 2.400 & NA \\
\hline Magnesium & 1.900 & 1.150 & 3.000 & 0.200 \\
\hline Sulphate & 5.000 & 0.170 & 0.430 & 100.000 \\
\hline Nitrate & 3.130 & 0.290 & 0.080 & 50.000 \\
\hline Phosphate & 0.090 & 0.640 & 0.240 & NA \\
\hline Chloride & 21.300 & 44.520 & 18.400 & 250.000 \\
\hline Lead & 0.005 & 0.010 & 0.000 & 0.010 \\
\hline Chromium & 0.004 & 0.010 & 0.010 & 0.050 \\
\hline Zinc & 0.040 & 0.020 & 0.020 & 0.300 \\
\hline Iron & 0.060 & 0.040 & 0.080 & 0.300 \\
\hline Cadmium & 0.000 & 0.000 & 0.000 & 0.000 \\
\hline Mercury & 0.000 & 0.000 & 0.000 & 0.000 \\
\hline
\end{tabular}

NA: Not Available; NSDWQ: Nigerian Standard for Drinking Water Quality (NIS, 2007). All parameters except $\mathrm{pH}$ and EC were measured in $\mathrm{mg} / \mathrm{l}$; EC was measured in $\mu \mathrm{S} / \mathrm{cm}$ and $\mathrm{pH}$ in moles/liter. 
The anions analyzed among the sites include chloride, sulphate, nitrate and phosphate. Furthermore the concentrations of chloride (21.300), sulphate (5.000) and nitrate (3.130) at the site were far below NIS (2007) stipulated values of $250 \mathrm{mg} / \mathrm{l}, 100 \mathrm{mg} / \mathrm{l}$ and $50 \mathrm{mg} / \mathrm{l}$ respectively.

Cadmium, iron, lead, chromium and zinc were among the heavy metals analyzed in this study. Heavy metals are toxic and poisonous in relatively higher concentrations. Two factors contribute to the deleterious effects of heavy metals as environmental pollutants. Firstly, they cannot be destroyed through biological degradation as in the case of most organic pollutants. Secondly, they are easily assimilated and can be bioaccumulated in the protoplasm of living organisms (Egborge, 1994). The concentrations of the heavy metals individually did not differ significantly $(\mathrm{p}>0.05$ ) the site, the concentrations of all the heavy metals except lead compared favourably with NIS (2007) stipulated values. Concentration of cadmium likewise chromium was undetectable in the groundwater sample obtained from site. Concentrations of zinc and iron were slightly lower at Costain. The concentration of lead was less than the NIS (2007) stipulated value of $0.01 \mathrm{mg} / \mathrm{l}$. Lead is the most common environmental contaminant found in soils. Unlike other metals, lead has no biological role, and is potentially toxic to even microorganisms (Sobolev \& Begonia, 2008). Its excessive accumulation in living organisms is always detrimental. Furthermore, lead exposure can cause seizures, mental retardation, and behavioural disorders in human beings (Adelekan \& Abegunde, 2011). The Water Quality Index (WQI) values computed for groundwater sample obtained from the Costain environ was 21.58.

Most of the ions in water and other matrix of the environment become pollutant at certain concentration; furthermore the adverse effects of some of these ions including ions of heavy metals which can be accumulated (Egborge, 1994) are of serious health concern. The accumulation of heavy metal in the human body could result to malfunctioning of organs (Jarup, 2003). Cr has been identified as carcinogenic agents, $\mathrm{Cd}$ as nephrotoxic agent and $\mathrm{Pb}$ as neutrotoxic and enzyme inhibitor (Ernest, 2010). The concentration of nitrate is of concern because of its toxicity. Nitrate concentrations greater than $10 \mathrm{mg} . \mathrm{NO}_{3}$ in drinking water have been known to cause methaemoglobinemia in infants, a disease characterized by cyanosis, a bluish colouration of the skin, the so-called "blue-baby" syndrome. Infants up to three months old are especially prone to this disease (Radojevic \& Bashkin, 1999). According to Ramakrishniah et al. (2009) the quality of groundwater at Costain peripheral was evaluated as being excellent and good for human consumption (Idehen, 2018).

\subsection{Physicochemical Analysis of Water in Third Cemetery}

The groundwater was slightly acidic at Third Cemetery (4.960) except at the Reference Site; electrical conductivity (EC), total dissolved and total suspended solids, nutrients including nitrate and phosphate, the alkali metals, heavy metals (excluding iron values which were high in the reference sites and cadmium and 
mercury which were not detectable in the water sample) values were low in the water sample obtained from Site. Generally chloride was the dominant anion on the site water sample, while the least of the same group were sulphate and nitrate for cemetery peripheral sites and reference site respectively.

The Water Quality Index (WQI) varied significantly $(p<0.05)$ while considering the parameters used in the computation. The values obtained while including all the parameters in the computation was 13.40

The common parameters influenced by decomposing activities in cemeteries include pH, EC, $\mathrm{Cl}, \mathrm{NO}_{3}, \mathrm{SO}_{4}, \mathrm{P}, \mathrm{Na}, \mathrm{K}, \mathrm{Ca}$ and Fe (Üçisik \& Rushbrook 1998; Young et al., 2002; Sawyer et al., 2003; Tredoux et al., 2004; Idehen \& Ezenwa, 2018). With the exception of $\mathrm{pH}, \mathrm{SO}_{4}$ and $\mathrm{Fe}$ the other parameters including $\mathrm{Cl}$, $\mathrm{NO}_{3}, \mathrm{Na}$, and $\mathrm{K}$ were generally higher in the groundwater samples obtained from the cemetery peripheral when compared to the Reference Site. Furthermore, Tredoux et al., (2004) suggested the inclusion of $\mathrm{Mn}, \mathrm{Cd}, \mathrm{Cr}, \mathrm{Cu}, \mathrm{Ni}, \mathrm{Pb}$ and $\mathrm{Zn}$ at high risk sites; these heavy metals especially $\mathrm{Pb}, \mathrm{Mn}, \mathrm{Cu}, \mathrm{Ni}$ and $\mathrm{Zn}$ were the most influencing parameters relating to the cemetery. These changes together with other variations discussed above can be seen as clear indications of the impact of the decomposing activities in the cemetery upon the quality of the water in aquifer underlain the area.

\section{Discussion of Geophysical Tomography in Third Cemetery}

The acquired two-dimensional electrical resistivity data covered section of the surface laterite, fine sand just below it, very coarse sand and section of medium sand. The sandy formation is porous and highly permeable, and hence the flow leachate through it is rapid. The clay layer at depth of $46 \mathrm{~m}(152 \mathrm{ft})$ underlain the well sorted coarse sand impede further downward migration of leachate plume and hence the coarse sand is most likely saturated with water forming the unconfined aquifer. The water table likely occurs between the very coarse sand and medium sand. As leachate plume is detected in the medium sand, water in the well sorted coarse sand will be contaminated. Laboratory analysis (at the Elite Environmental Consultants and Laboratories Ltd.) of the water sample taken from borehole in the vicinity (NEW BENIN POLICE STATION ) show high Electrical Conductivity (EC).These abnormal values probably due to leachate plumes released into the shallow aquifer serving as the regional water supply source. If this shallow aquifer is polluted, there is high probability that the nearby deep confined, coarse sand aquifer at depth of $60 \mathrm{~m}(200 \mathrm{ft})$ is at risk (if the protection capacity of the underlain clay is not satisfactory). The repeated resistivity survey revealed displacement of the detected plumes over a time. The geoelectric models obtained for the survey displayed leachate plumes starting from the laterite (the burial environment) down to the sandy formation (the regional water supply source) (Idehen, 2018).

2-D Geoelectric Models of Typical Cemetery and Typical Dumpsites (Figures 3-8) (Idehen, 2019). 


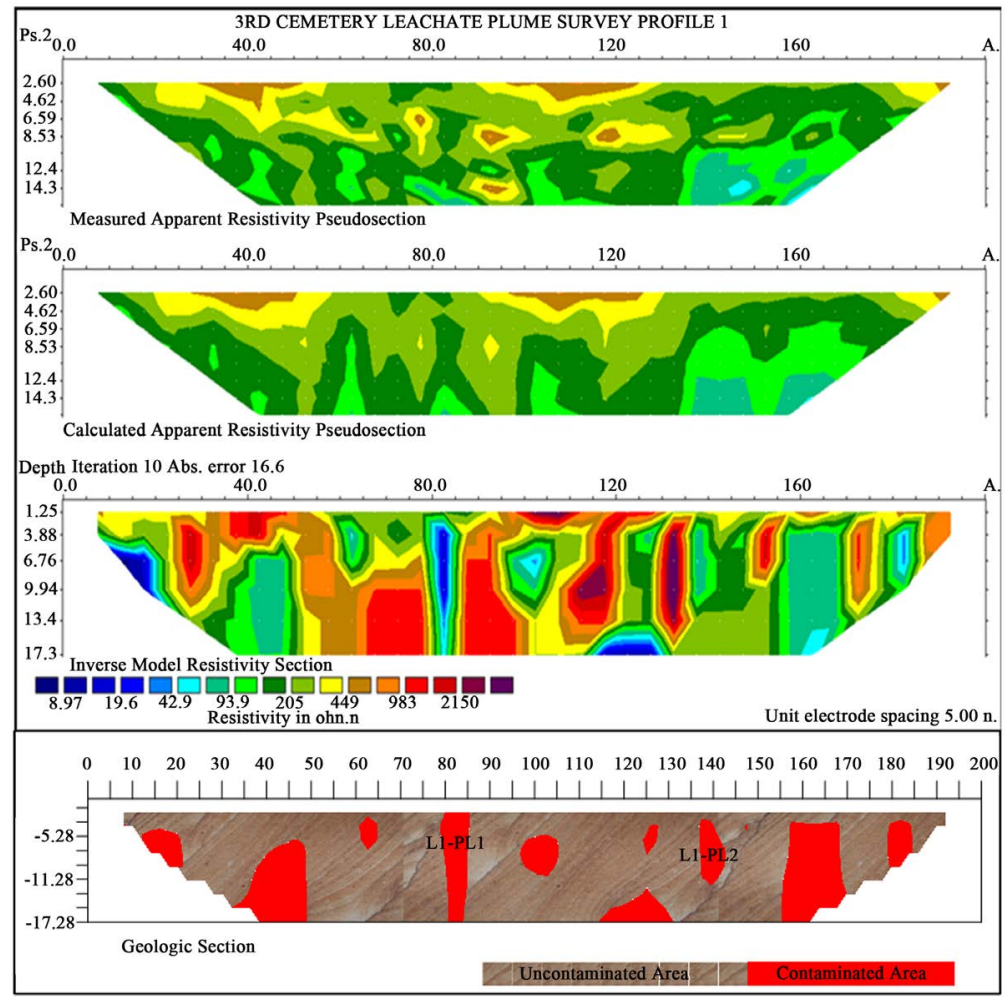

Figure 3. 2-D geoelectric model of third cemetery survey profile 1.

COSTAIN DUMPSITE SURVEY

Ps.2 0.0 5.0 10.0 15.0 20.025.030.035.040.0 45.050.055.060.0 65.070.075.080.085.0 90.095.0100 105110 115120125 A.

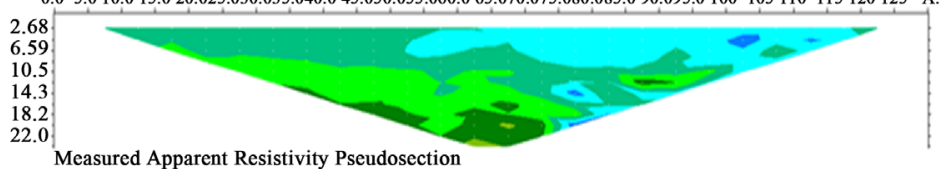

Measured Apparent Resistivity Pseudosection

Ps.2 0.0 5.0 10.0 15.0 20.025.030.035.040.0 45.050.055.060.0 65.070.075.080.085.0 90.095.0100 105110 115120125 A.

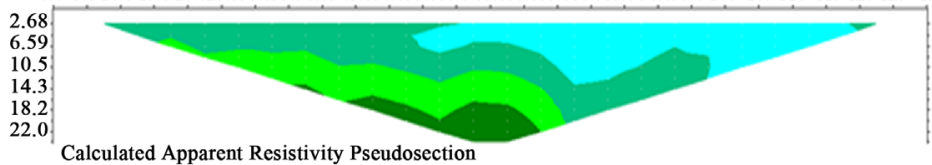

Calculated Apparent Resistivity Pseudosection

Depth Iteration 10 Abs. error 9.1

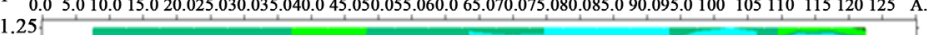

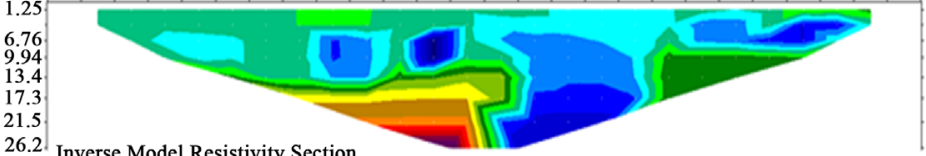

26.2 Inverse Model Resistivity Section

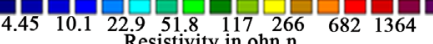

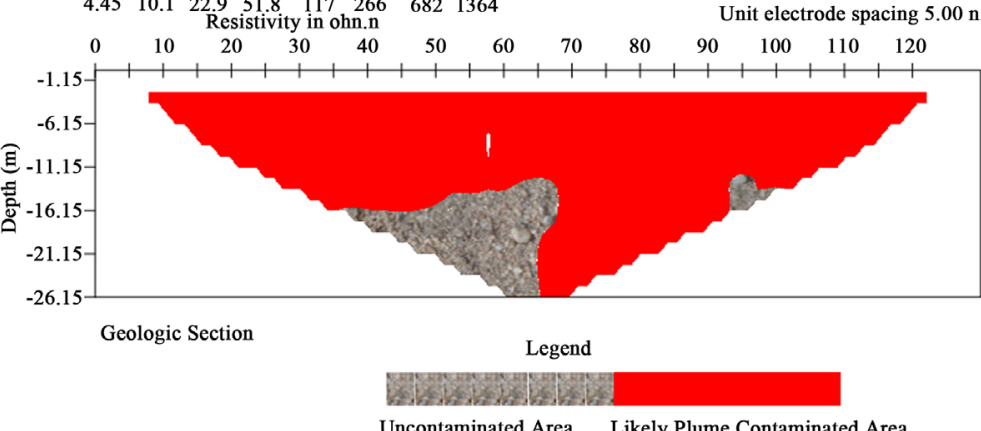

Figure 4. 2-D geoelectric models of costain dumpsite survey profile. 


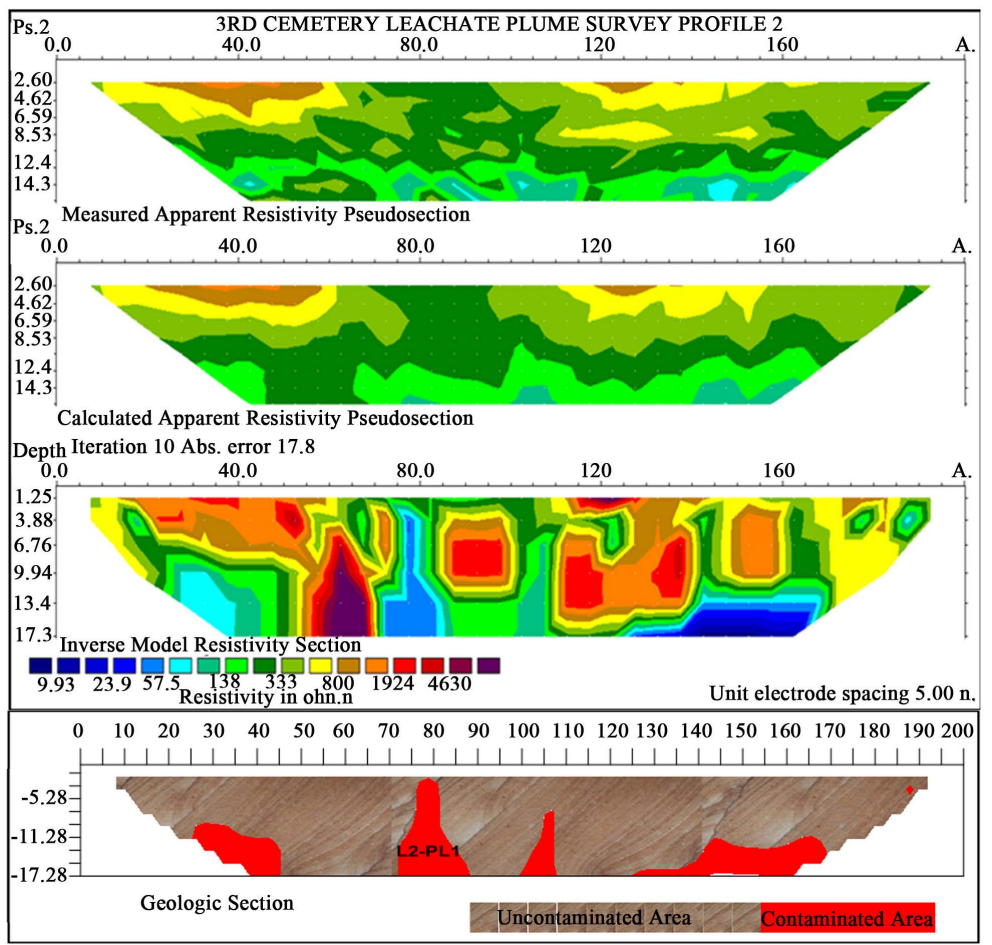

Figure 5. 2-D geoelectric model of third cemetery survey profile 2.
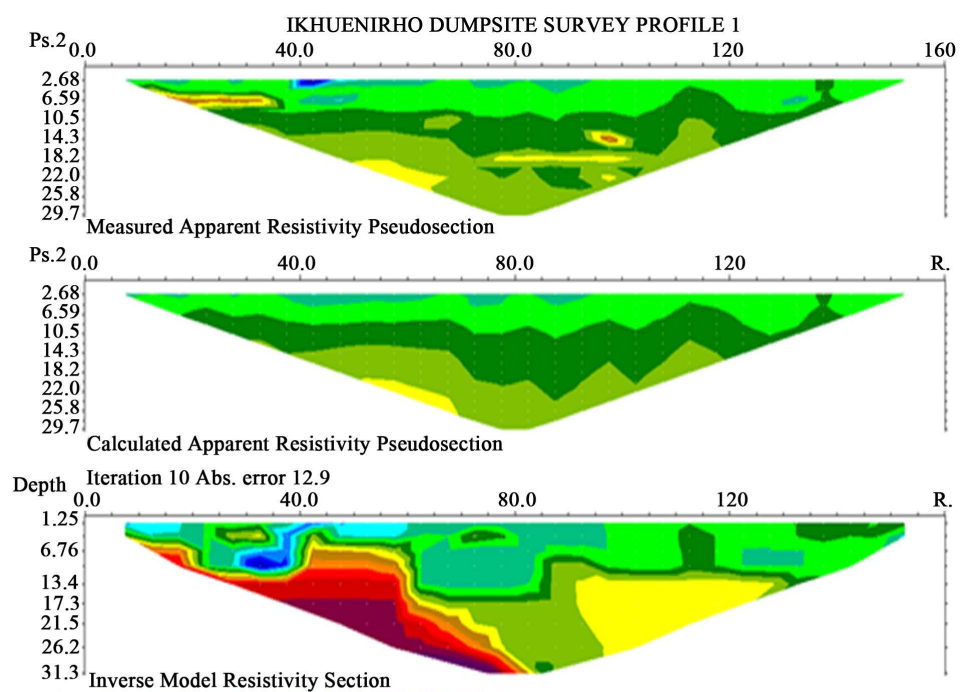

$\begin{array}{llllllll}5.56 & 13.8 & 34.5 & 85.8 & 214 & 532 & 1323 & 3293\end{array}$ Resistivity in ohn.n

Unit electrode spacing $5.00 \mathrm{n}$.

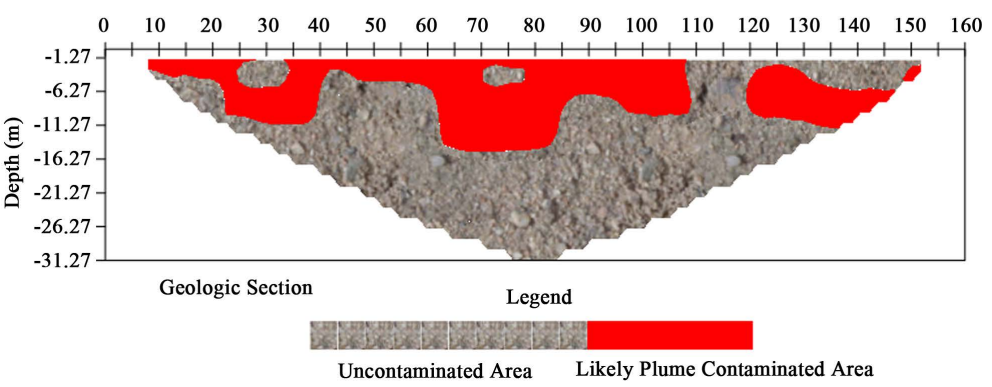

Figure 6. 2-D geoelectric models of ikhuenirho dumpsite survey profile. 


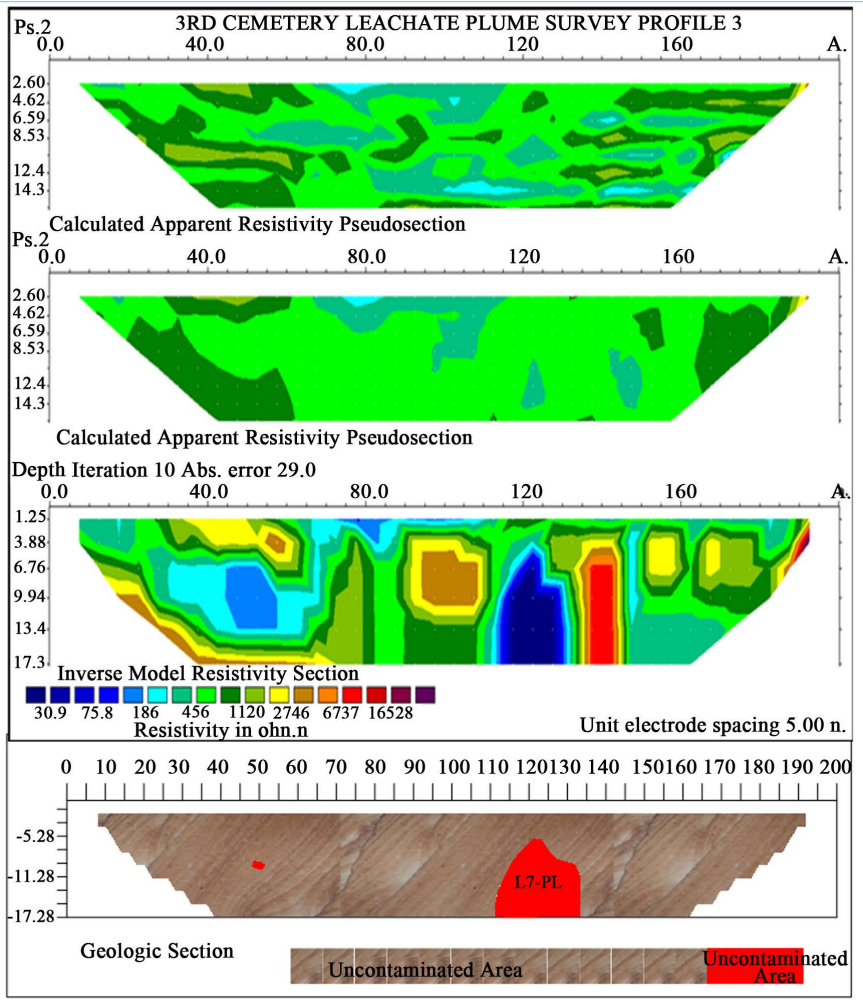

Figure 7. 2-D geoelectric models of third cemetery survey profile 3.

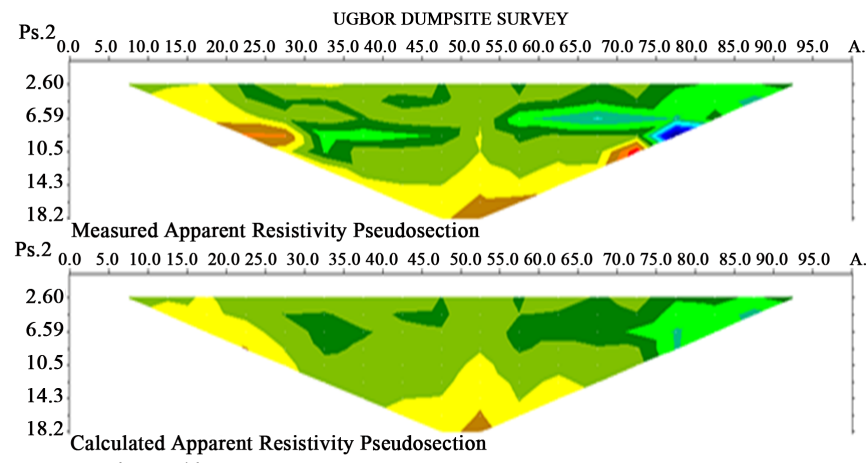

Depth Iteration 10 Abs. error 23.1

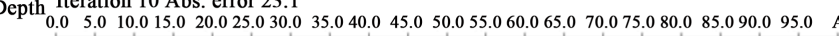

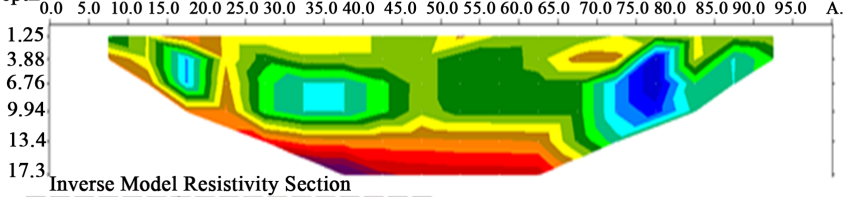

17.3 Inverse Model Resistivity Section

$1.052 .91 \quad 8.05 \quad 22.3 \quad 61.5 \quad 170 \quad 471 \quad 1302$

Resistivity in ohn.n

Unit electrode spacing $5.00 \mathrm{n}$.

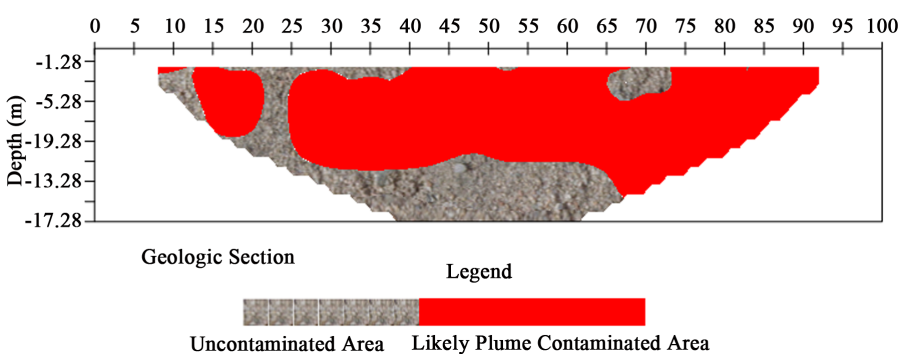

Figure 8. 2-D geoelectric models of ugbor dumpsite survey profile. 


\section{Conclusion}

\section{Comparative Analysis (Third Cemetery and Costain Dumpsite)}

From Table 1 the $\mathrm{pH}$ values at both Third Cemetery and Costain Dumpsite were lower than the value at the Reference Site. The value at Third Cemetery being the lowest (4.960) showed that the water at the Cemetery is more acidic due to the infiltration from the burial loads.

The Electrical Conductivity (EC) values in Third Cemetery and Costain Dumpsite (118.000 and 99.900) respectively, are higher than the value at Reference Site. This implies that the resistivity values are also lower, which depicts the presence of leachate plumes in the above mentioned sites.

The values of Total Dissolved Solid (TDS) and Calcium in Third Cemetery were higher than that of Costain Dumpsite. Magnesium, Sulphate and Nitrate were found to be of higher values in Costain Dumpsite than Third Cemetery. Phosphate, Chlorides, Lead and Chromium have higher values in Third Cemetery than Costain Dumpsite. Zinc and Iron had higher values in Costain Dumpsite than Third Cemetery due to the different solid wastes and other refuse dump deposited at the Dumpsite. The 2-D Geological Models showed that both Third Cemetery and Costain Dumpsite contained leachate plumes of various degrees as indicated by the low resistivity values obtained at both sites which infiltrated into the groundwater. The geoelectric formation of both sites showed that laterite, clayed sand, sand and clay exist. The values of Water Quality Index (WQI) of groundwater samples in Third Cemetery and Costain Dumpsite were found to be 13.40 and 21.58 respectively which indicated that the quality of water at both Third Cemetery and Costain Dumpsite is good for drinking and other domestic purposes (less than 100, Ramakrishniah et al., 2009) though with some degrees of contamination.

\section{Conflicts of Interest}

The author declares no conflicts of interest regarding the publication of this paper.

\section{References}

Adekunle, I. M., Adetunji, M. T., Gbadebo, A. M., \& Banjoko, O. B. (2007). Assessment of Groundwater Quality in a Typical Rural Settlement in Southwest Nigeria. International Journal of Environmental Research and Public Health, 4, 307-318. https://doi.org/10.3390/ijerph200704040007

Adelekan, B. A., \& Abegunde, K. D. (2011). Heavy Metals Contamination of Soil and Groundwater at Automobile Mechanic Villages in Ibadan, Nigeria. International Journal of Physical Sciences, 6, 1045-1058.

Anthony Ravindran, A. I. and Mohd. Abdul Kadar Prabhu H. (2012). Groundwater Exploration Study Using Wenner-Schlumberger Electrode Array through W-4 2D Resistivity Imaging Systems at Mahapallipuram, Chennai, Tamilanadu, India. Research Journal of Recent Sciences, 1, 36-40.

Edet, A. E. (1993). Groundwater Quality Assessment in Parts of Eastern Niger Delta. En- 
vironmental Geology, 22, 41-46. https://doi.org/10.1007/BF00775283

Egborge, A. B. M. (1994). Water Pollution in Nigeria. In: Biodiversity and Chemistry (Vol. 1, 331 p.). Warri River, Warri: Ben Miller Books.

Ernest, H. (2010). A Textbook of Modern Toxicology (648 p.). Hoboken, NJ: John Wiley \& Sons, Inc.

Fisher, G. J., \& Croukamp, L. (1993). Ground Water Contamination and Its Consequences, Resulting from the Indiscriminate Placing of Cemeteries in the Third World Context. Conference Africa Needs Groundwater. Johannesburg, South Africa: University of the Witwatersrand.

Ibhadode, C. A. E., Dirius, A. R., \& Akhimien, F. O. (2017). Adequacy or Otherwise of Cemetery Space for Sustainable Human Body Disposal in Benin City, Nigeria. Ethiopian Journal of Environmental Studies \& Management, 10, 566-571.

Idehen, O. (2018). TimeLapse Geoforensic Investigation of Leachate Plume Migration from ActiveCemetery in Benin City, Nigeria. Ph.D. Thesis, Benin: University of Benin.

Idehen, O. (2019). The Impact of Typical Cemetery on Groundwater Using Both Geophysical Techniques and Physicochemical Analyses of Water in South-South, Nigeria. International Journal of Applied Science, 2, 12. https://doi.org/10.30560/ijas.v2n2p12

Idehen, O., \& Ezenwa, I. M. (2019). Influence of Third Cemetery Location on the Quality of Domestic and Groundwater Resources in Benin City, Nigeria. Journal of Applied Sciences and Environmental Management, 23, 5-11.

https://doi.org/10.4314/jasem.v23i1.1

Ikem, A., Osibanjo, O., Shridar, M. K. C., \& Sobande, A. (2002). Evaluation of Groundwater Quality Characteristics Near Two Waste Sites in Ibadan and Lagos, Nigeria. Water, Air, and Soil Pollution, 140, 307-333. https://doi.org/10.1023/A:1020165403531

Ikhile, C. I., \& Oloriode, D. O. (2011). Impact of Climate Change on Underground-Water Resources Development in Benin-Owena River Basin, Edo State, Nigeria: Case Study. European Journal of Scientific Research, 63, 272-278.

Ikhuoria, I. A. (1987). Urban Land Use Patterns in Traditional Nigeria City: A Case Study of Benin City. Land Use Policy, 4, 62-75. https://doi.org/10.1016/0264-8377(87)90009-3

Jarup, L. (2003). Hazards of Heavy Metal Contamination. British Medical Bulletin, 68, 167-182. https://doi.org/10.1093/bmb/ldg032

Jonker, C., \& Olivier, J. (2012). Mineral Contamination from Cemetery Soils: Case Study of Zandfontein Cemetery, South Africa. International Journal of Environmental Research and Public Health, 9, 511-520. https://doi.org/10.3390/ijerph9020511

Loke, M. H. (2014). Electrical Imaging Surveys for Environmental and Engineering Studies. A Practical Guide to 2-D and 3-D Surveys.

Majolagbe, A. O., Kasali, A. A., \& Ghaniyu, L. O. (2011). Quality Assessment of Groundwater in the Vicinity of Dumpsites in Ifo and Lagos, South Western Nigeria. Advances in Applied Sciences Research, 2, 289-298.

Neckel, A., Costa, C., Mario, D. N., Sabadin, C. E. S., \& Bodah, E. T. (2016). Environmental Damage and Public Health Threat Caused by Cemeteries: A Proposal of Ideal Cemeteries for the Growing Urban Sprawl. Brazilian Journal of Urban Management, 9, 216-230. https://doi.org/10.1590/2175-3369.009.002.ao05

Nigerian Industrial Standard-NIS (2007). Nigerian Standard for Drinking Water Quality. NIS Nigerian Industrial Standard NIS 554: 2007. Nigerian Standard for Drinking Water Quality ICS 13,060.20 (c) SON 2007.

Omoboriowo, A. O., Chiaghanam, O. I., Soronnadi-Ononiwu, G. C., Acra, E. J., Okengwu, K. O., Ugwueze, C. U., Yikarebogha, Y., \& Momta, P. S. (2012). Appraisal of the 
Groundwater Quality in Arochukwu Area, Afikpo Basin, Nigeria. The International Journal of Science \& Technology, 2, 788-793.

Omofonmwan, S. I., \& Eseigbe, J. O. (2009). Effects of Solid Waste on the Quality of Underground Water in Benin Metropolis, Nigeria. Journal of Human Ecology, 26, 99-105. https://doi.org/10.1080/09709274.2009.11906171

Radojevic, M., \& Bashkin, V. N. (1999). Practical Environmental Analysis (645 p.). Science Park, Cambridge, UK: Royal School of Chemistry, Thomas Graham House.

Ramakrishniah, C. R., Sadashivaiah, C., \& Ranganna, G. (2009). Assessment of Water Quality Index for the Groundwater in Tumkur Taluk. E-Journal of Chemistry, 6, 523-530. https://doi.org/10.1155/2009/757424

Sawyer, C. N., McCarthy, P. L., \& Parkin, G. F. (2003) Chemistry for Environmental Engineering and Science (5th ed., 752 p.). New York: McGraw-Hill.

Schraps, W. G. (1972). The Relevance of Soil Filtration Properties for the Installation of Cemeteries. 16, 225-229.

Short, K., \& Stauble A. J. (1967). Outline of the Geology of Niger Delta. AAPG Bulletin, 51, 761-779. https://doi.org/10.1306/5D25C0CF-16C1-11D7-8645000102C1865D

Sobolev, D., \& Begonia, M. F. (2008). Effects of Heavy Metal Contamination upon Soil Microbes. International Journal of Environmental Research and Public Health, 5, 450-456.

Spongberg, A. L., \& Becks, P. M. (2000). Inorganic Soil Contamination from Cemetery Leachate. Water, Air, and Soil Pollution, 117, 313-327. https://doi.org/10.1023/A:1005186919370

Tredoux, G., Cavé, L., \& Engelbrecht, P. (2004). Groundwater Pollution: Are We Monitoring Appropriate Parameters? Water SA, 30, 114-119.

https://doi.org/10.4314/wsa.v30i5.5180

Üçisik, A. S., \& Rushbrook, P. (1998). The Impact of Cemeteries on the Environment and Public Health. World Health Organization Regional Office for Europe. http://apps.who.int/iris/bitstream/10665/108132/1/EUR ICP EHNA 0104 01(A).pdf

Young, C. P., Blackmore, K. M., Leavens, A., \& Reynolds, P. J. (2002). Pollution Potential of Cemeteries. Environment Agency England and Wales.

https://www.gov.uk/government/uploads/system/uploads/attachment data/file/290607 Isprp2-024-1-e-e.pdf

Zychowski, J., Lach, J., \& Kolber, M. (2000). Physico-Chemical Features of Groundwaters on Cemeteries of South-Eastern Poland. In J. Burchard (Ed.), State and Anthropogenic Changes of Water Quality in Poland (Vol. 1, pp. 261-269). 